\title{
Assessing and Improving the Use of Online Information About Child Development, Education, Health, and Well-Being in Low-Education, Low-Income Parents: Protocol for a Mixed-Methods Multiphase Study
}

Pierre Pluye $^{1}$, MD, PhD; Christine Loignon ${ }^{2}$, PhD; François Lagarde ${ }^{3}$, MA; Geneviève Doray ${ }^{4}$, B.A.; Reem El Sherif ${ }^{1}$, MSc, MBBCh; Vera Granikov ${ }^{1}$, MLS; Araceli Gonzalez Reyes ${ }^{1}$, MSc; Mathieu Bujold ${ }^{1}, \mathrm{PhD}$; Roland Grad ${ }^{1}, \mathrm{MSc}$, MD, FCFP; Gillian Bartlett ${ }^{1}$, PhD; Melanie Barwick ${ }^{5}$, CPsych, PhD; Tibor Schuster ${ }^{1}$, PhD; Emmanuelle Turcotte ${ }^{1}$, $\mathrm{PhD}$; France Bouthillier ${ }^{6}, \mathrm{PhD}$

\footnotetext{
${ }^{1}$ Department of Family Medicine, McGill University, Montréal, QC, Canada

${ }^{2}$ Département de médecine de famille, Université de Sherbrooke, Longueuil, QC, Canada

${ }^{3}$ Fondation Lucie et André Chagnon, Montréal, QC, Canada

${ }^{4}$ Naître et grandir, Fondation Lucie et André Chagnon, Montréal, QC, Canada

${ }^{5}$ The Hospital for Sick Children, Research Institute, Toronto, ON, Canada

${ }^{6}$ School of Information Studies, McGill University, Montréal, QC, Canada
}

\section{Corresponding Author:}

Pierre Pluye, MD, PhD

Department of Family Medicine

McGill University

3e étage

5858 chemin de la Côte-des-Neiges

Montréal, QC, H3S 1Z1

Canada

Phone: 1 (514) 3987375

Fax: 1 (514) 3984202

Email: pierre.pluye@mcgill.ca

\section{Abstract}

Background: This study is born from a partnership between Web editors of Naître et grandir (N\&G) and AboutKidsHealth (AKH) and researchers who developed and validated the Information Assessment Method (IAM). N\&G and AKH are popular Canadian websites with high-quality comprehensive information about child development, education, health, and well-being. IAM allows parents to assess online information and provide feedback to Web editors. High-quality online consumer health information improves knowledge, self-efficacy, and health. However, low-socioeconomic status (SES) parents underuse N\&G and IAM, despite these parents being more likely to report decreased worries and increased confidence as outcomes from N\&G information.

Objective: The study is aimed to improve low-SES parents' use of online child information and interaction with Web editors and explore subsequent health outcomes for parents and children.

Methods: Multiphase mixed-methods design. Our general approach is centered on organizational participatory research. In phase 1 , we will conduct a qualitative interpretive study to identify barriers and facilitators to using N\&G information and to interacting with N\&G editors via IAM; interview more than 10 low-SES parents about their experience with N\&G and IAM and more than 10 nonusers of N\&G and IAM; and use thematic analysis to identify main barriers and facilitators. In phase 2, we will integrate parents' views (phase 1 findings) in $\mathrm{N} \& \mathrm{G}$ and IAM and implement a new version: IAM+N\&G+. In phase 3, we will conduct a quantitative prospective longitudinal study (pre-/postimplementation monitoring of knowledge use and outcomes). We will compare the use of original (IAM and N\&G) and new (IAM+ and N\&G+) versions using Google Analytics variables, IAM variables, a material and social deprivation index, and demographics. We anticipate increased use post implementation (linear mixed modeling). In phase 4, we will conduct a qualitative descriptive study on outcomes of information use. We will interview 
more than 30 low-SES parents who receive and rate the N\&G+ newsletter using IAM+ and analyze data in the form of life histories to describe how parents and children experience perceived outcomes.

Results: The project was funded in 2017 by the Canadian Institutes of Health Research and received an ethics approval by the McGill University's institutional review board. Data collection for phase 1 was completed in 2018. Phases 2 to 4 will be conducted until 2020. Findings from this study will also be used to develop a free toolkit, useful to all Web editors, with recommendations for improving health information for low-SES persons and interactions with them using IAM.

Conclusions: The results of this study will provide a deep understanding of how low-SES parents use online child information and interact with Web editors. Following the implementation of IAM+N\&G+, results will also elucidate subsequent health outcomes for low-SES parents and children after interaction with Web editors has been optimized.

International Registered Report Identifier (IRRID): PRR1-10.2196/9996

(JMIR Res Protoc 2018;7(11):e186) doi: 10.2196/resprot.9996

\section{KEYWORDS}

consumer health information; information technology; primary health care; knowledge translation; literacy; vulnerable populations

\section{Introduction}

\section{Rationale}

Early life experience is a determinant of social inequalities in physical, mental, and social well-being [1-6]. Children living in poverty are more likely to suffer from developmental and health problems, and childhood interventions can decrease incidence and prevalence of these problems [7-12]. The proposed project is aimed to assess and improve a childhood intervention: the Naître et grandir (N\&G) website and newsletter on child development, education, health, and well-being, which includes the Information Assessment Method (IAM) that allows $\mathrm{N} \& \mathrm{G}$ readers to continuously assess, and subsequently the $\mathrm{N} \& \mathrm{G}$ editors to improve, the content shared on the $N \& G$ website and newsletter.

Parents with low education and low income, hereafter referred to as parents with low socioeconomic status (SES), typically have a low literacy level (limited ability to acquire, understand, evaluate, and use written information). Low parental literacy level is particularly detrimental to child health: a low literacy level is associated with worse health status, difficulties accessing health care, and poorer preventive health behavior and self-management of health problems [13-23].

Education and income are the most important SES indicators, and together, they are strongly associated with child health status $[24,25]$. According to research on information-seeking behavior, parents with low SES have greater information needs than parents with high SES [26]. The use of high-quality online information can improve quality of life and have positive family, economic, and social impacts on low-SES parents, including refugee and homeless parents [27-31]. High-quality information and literacy-related interventions can reduce unnecessary calls and visits to health professionals, increase knowledge and self-efficacy, and improve health [16-19,32-47].

$\mathrm{N} \& \mathrm{G}[48]$ is a website independent from industry funding that provides high-quality information (based on research syntheses and validated by experts) on child development, education, health, and well-being. N\&G users can access hundreds of information pages ( 1 page per topic) that are organized in age group categories, ranging from pregnancy to the age of 8 years. $\mathrm{N} \& \mathrm{G}$ also produces a weekly newsletter to support parents, including those with a low literacy level, having children under the age of 8 years.

$\mathrm{N} \& \mathrm{G}$ partnered with investigators from McGill University to validate and implement the IAM to continuously assess and improve content shared on the N\&G website and newsletter [49-53]. In line with the Canadian Institutes of Health Research (CIHR)'s definitions [54], the IAM is a knowledge translation tool for monitoring $\mathrm{N} \& \mathrm{G}$ information use, and its impact on parents is measured by expected health/well-being benefits. It is also fostering parent engagement by enabling parents to interact with $\mathrm{N} \& \mathrm{G}$ editors by providing feedback on the information content. The IAM questionnaire includes 7 questions (with clickable answers and 2 comment boxes), allowing users to rate on the situational relevance, cognitive/affective impact, intention to use and expected benefits of specific information content ( $\mathrm{N} \& \mathrm{G}$ information page), and write comments.

During our pilot phase (September 1, 2014, to August 31, 2016), we collected 34,021 IAM ratings (completed IAM questionnaires) from parents, relatives, and professionals (education, health, and social services) who read N\&G content. In line with studies on social inequalities in Web information use [55-61], the statistical analysis of these ratings revealed a social gradient: low-SES parents underuse $N \& G$ and the IAM (Figure 1). Results also indicated that low-SES parents are more likely to report decreased worries and increased confidence as a result of using N\&G information [50]. There is a need to understand this gradient to improve N\&G content and reach low-SES parents and a need to explore how the use of knowledge translates into health and well-being outcomes for low-SES parents and children. 
Figure 1. Social gradient in assessing Naître et grandir (N\&G) information with Information Assessment Method (IAM). A dot represents the total number of IAM ratings completed by all N\&G newsletter subscribers living within the postal code areas of a Canadian centile of Material Deprivation. There is a negative linear relationship as areas with higher deprivation have a lower proportion of newsletter ratings/subscribers. The correlation coefficient is $-.42(P<.001)$.

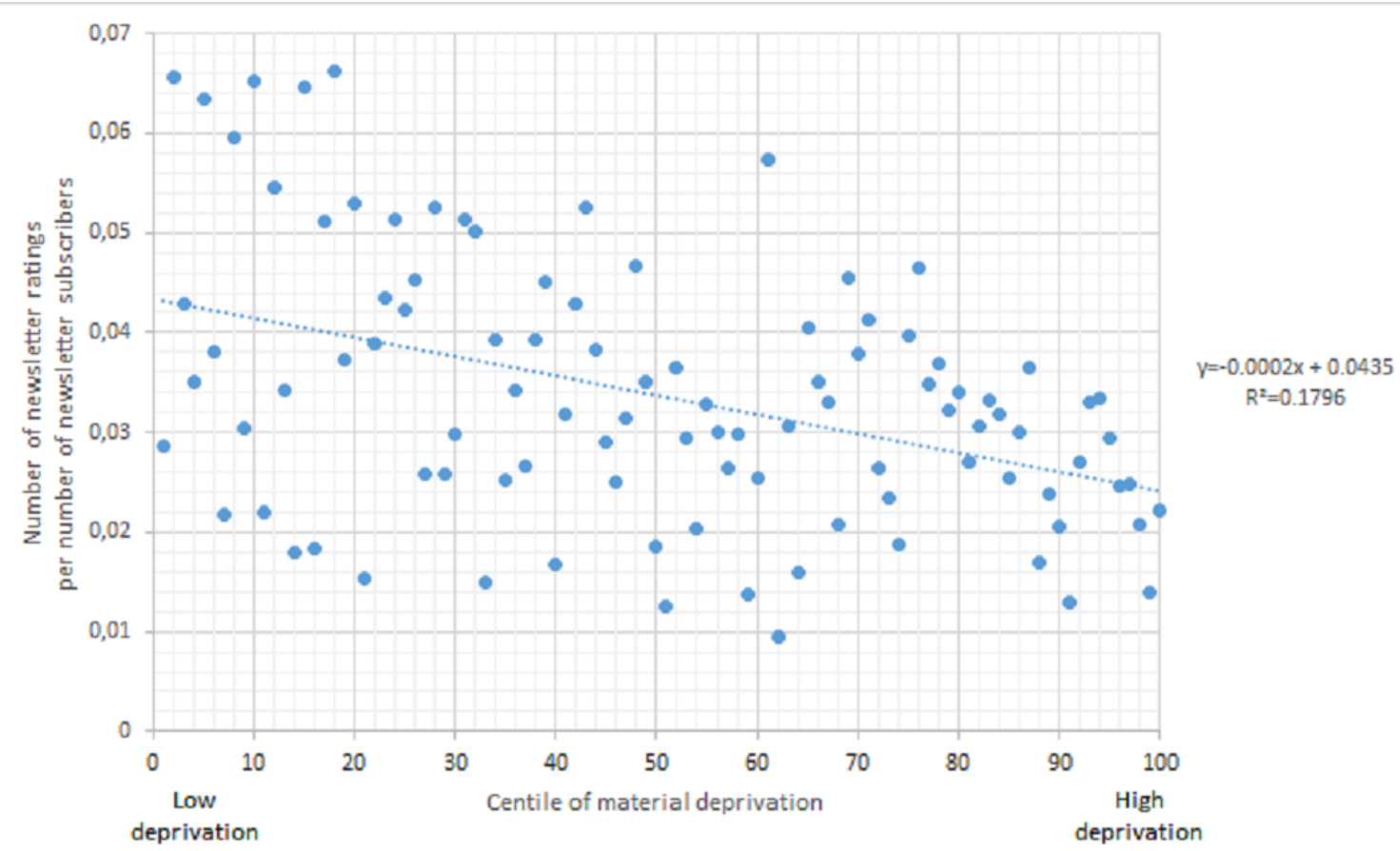

\section{Goal and Objectives}

This study (research protocol) has been recently funded by CIHR. As per CIHR's definition of knowledge translation ("making people aware of knowledge and facilitating knowledge use to improve health") [62], our goal is to improve how low-SES parents engage with and use online information about child development, education, health, and well-being; learn how this format for knowledge sharing translates to improved health and well-being outcomes for low-SES parents and their children; and explore their interaction with Web editors to influence content (responsible for websites' content). On the basis of the $\mathrm{N} \& \mathrm{G}$ team's (the director and 2 coordinators) questions and using the Knowledge-to-Action framework [63], we determined 4 research objectives:

- Objective 1: Identify low-SES parents' views on barriers and facilitators to accessing, understanding, and using N\&G information content and to interacting with $\mathrm{N} \& \mathrm{G}$ editors via the IAM.

- Objective 2: Adapt N\&G content/functions and the IAM tool (user-centered design) to reduce barriers and optimize facilitators identified in phase 1 and implement new versions labeled $\mathrm{N} \& \mathrm{G}+$ and IAM+.

- Objective 3: Evaluate whether N\&G+ and IAM+ result in a higher proportion of low-SES parents engaging with the $N \& G$ site and the content provided and interacting with editors via the IAM.
- $\quad$ Objective 4: Describe how expected health and well-being benefits of $\mathrm{N} \& \mathrm{G}+$ information use (reported via IAM+) are experienced by parents with low SES and their children.

\section{Systematic Literature Review and Theoretical Model}

The nominated principal investigator (NPI) led a CIHR-funded systematic review and proposed a comprehensive harmonized typology of (1) outcomes associated with the use of online consumer health information and (2) conditions (network and resources) leading to these outcomes [64-67]. A total of 68 studies were analyzed using framework synthesis [68,69]. This synthesis was based on an initial framework derived from information studies [49,70-78] and led to propose an innovative theoretical model (Figure 2) [66,67]. This model includes positive and negative health outcomes of online consumer health information in a primary care context and is (information) consumer oriented.

The model comprises 13 main concepts (42 factors and outcomes) and will be used in this study to inform data collection and analysis, for example, the phase 1 qualitative interview guide and interpretive thematic analysis. The model will contribute to establish a chain of evidence linking ultimate outcomes of information (such as health outcomes), intermediary outcomes (such as cognitive impact of information), and conditions associated with outcomes (information needs and seeking behaviors and contextual factors). 
Figure 2. Theoretical model.

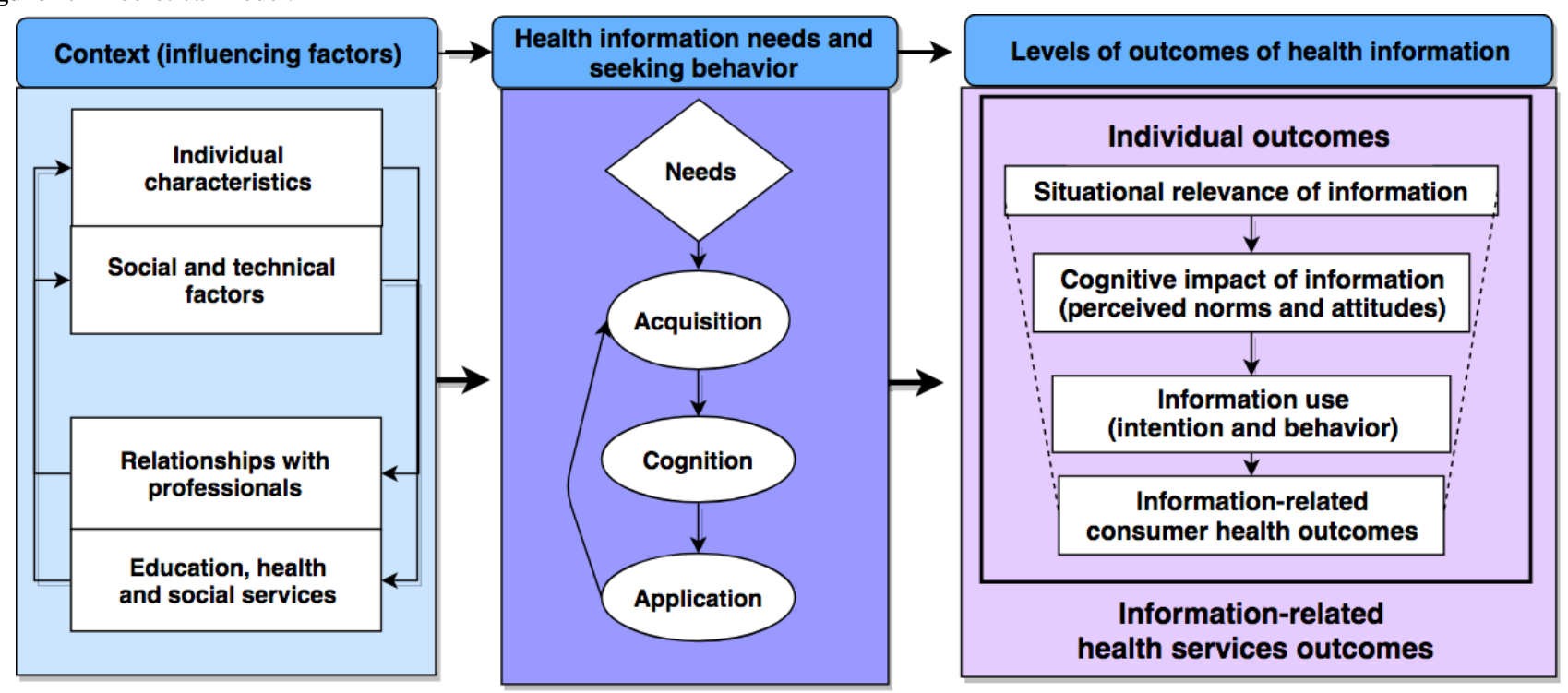

\section{Outcomes}

The model includes an organizational level of information outcome (eg, increased or decreased use of health services) and 4 individual levels of outcomes of information. The latter outcomes reflect how information is valuable from the consumer's perspective: situational relevance, cognitive impact, use of information (conceptual, legitimating, instrumental, and symbolic use), and subsequent health and well-being outcomes.

\section{Conditions}

The model includes conditions associated with outcomes of information in relation to a specific situation: a particular information object is acquired or delivered (eg, a Web page or a newsletter) in a particular situation (eg, before or during or after an encounter with someone) directly or with help from a relative or a professional. The main conditions are information needs and seeking behaviors; individual characteristics (such as electronic health literacy); social and technical factors (such as social networks); relationships with professionals (such as teachers, clinicians, and social workers); and access to education, health, and social services. The first phase of this study will specifically look into conditions experienced by low-SES parents, such as media competence.

Direct acquisition of online information depends on an impetus to search (motivation), momentary internet connection, internet search skills, and one's ability to understand the content that may or may not be adapted to their individual literacy level [79-81]. Approximately $95 \%$ of parents of preschool children have direct individual access to the internet in Quebec [61], and parents can also access it at office workplaces and public libraries [79-81]. Literacy level is generally defined as the degree to which a person has the ability to "acquire, understand, evaluate, and use information" needed to obtain services and make appropriate decisions [23]. Computer literacy, information literacy, and health literacy are interdependent (eg, a person with a low literacy level has a low level of health literacy). Culture is central in literacy, and one's literacy level depends on one's ability to understand systems of symbols from one's own culture or a dominant culture and language, for example, immigrants and refugees may have a higher literacy level in their country of origin compared with their adoptive country [23]. As mentioned in our model, the literacy level is situational and contextual, given that a social network can compensate for an individual's low literacy level.

Mediated (by someone else) acquisition of information is very common. The absence of an individual connection $24 / 7$ is no longer the primary barrier to seeking health information [80]; for example, our pilot data show that $18.1 \%$ of IAM ratings concerned N\&G information seeking for someone else's child (eg, relative's, friend's, neighbor's, or client's child). Even homeless parents or recent immigrants and refugees can acquire online consumer health information directly or mediated by their social network, including community organizations; public libraries; and education, health, and social services [23,27-31]. Indeed, information studies show that consumers combine mediated information with direct acquisition of online health information, the latter allowing them to probe information provided by professionals [64-67]. For analytical purpose, we conceive these combinations as the interpenetration of social systems centered on communicative action, for example, the health system (mediated access) and a consumer parent system (direct access and mediated access via their social network) [82-85].

\section{Significance}

Our project focuses on all Canadian parents with low SES who acquire (direct or mediated) online information about child development, education, health, and well-being. In Canada, $42 \%$ of nonelderly adults $[16,17]$ and $15 \%$ of children live in low-income households [86]. In Quebec, $36 \%$ of parents report living in poverty [87]. The demand for information is very high, resulting in frequent internet searches; for example, parents search the internet for child-related information on average 1.3 times per week in Quebec, and 73\% of parents report that the internet constitutes their first-line source of parenting information [88]. 
Table 1. Main features of Naître et grandir and AboutKidsHealth.

\begin{tabular}{lll}
\hline Main features & Naître et grandir [48] & AboutKidsHealth [94] \\
\hline $\begin{array}{l}\text { Website annual traffic } \\
\text { Information }\end{array}$ & $\begin{array}{l}\text { 24 million worldwide visits } \\
\text { Developmental, educational, health, and well-being information } \\
\text { about children aged under 8 years }\end{array}$ & $\begin{array}{l}\text { Health information about children aged under 19 years } \\
\text { Language }\end{array}$ \\
$\begin{array}{ll}\text { French } \\
\text { Targeted audience }\end{array}$ & Parents, relatives, and caregivers & English, French, and 10 other languages \\
\hline
\end{tabular}

Specifically, our project is important for about half the population of parents of children under 19 years, namely, parents with a low literacy level. Low literacy is a major concern in Canada [16,17,19,20,23]. Results of the 2011 to 2012 survey of a representative sample of 25,267 Canadian parents aged 16 to 65 years showed that $49 \%$ of parents have a low literacy level: $[89,90]$ they have difficulty finding, understanding, and using information presented in a dense or lengthy text; navigating complex digital texts; interpreting and evaluating information (constructing meaning); and disregarding irrelevant or inappropriate content when there is competing information (including when correct content is more prominent). Furthermore, our results may help any parent who faces a transitory low literacy level because of a stressful situation. This interdependence between information and emotion is well established in the information literature [91,92].

Our project nevertheless does not focus on the few information-poor parents without access (direct or mediated) to online information. In the United States, only $1 \%$ of 18 - to 29 -year olds did not use the internet in 2015 [93]. The Quebec 2015 survey of a representative sample of 23,693 parents of preschool children showed that only $1.5 \%$ of parents never know where to find child information [61]. According to information studies, the information-poor parents (1) perceive themselves as persons who cannot be helped, (2) adopt self- or group-protective behaviors, (3) are secretive and mistrust others, and (4) consider exposure to information as a risk (harm outweighing benefits) [30].

Our project engages a partnership between $\mathrm{N} \& \mathrm{G}$ and AboutKidsHealth (AKH) [94], both popular comprehensive Web-based resources (Table 1). Both resources contain text with a readability level below high school (this level may be higher for disease-related information), visual illustrations, and complementary simple illustrative videos. For each Web page, an audio help system highlights words as they are spoken. In 2016, our librarian did an environmental scan of Canadian parental websites and found multiple specialized resources but only 12 comprehensive resources (including $\mathrm{N} \& \mathrm{G}$ and $\mathrm{AKH}$ ).

Although this study is a priority in a Canadian context, our results can be important to and applied by all Web editors who provide health information, thereby benefitting all adults with a low literacy level (not only parents). For example, Health Canada policies recommend funding projects that aim to improve access to, and conduct research on, information for Canadians with a low literacy level [23]. Information systems are key components of health systems and crucial to meet human rights and the democratic right to know and communicate [31,95-100]. Among adults, the most frequent searches for information are about health [101]. The demand for high-quality low-literacy health information is, hence, very high.

\section{Methods}

\section{Organizational Participatory Research Approach}

Our project uses an organizational participatory research (OPR) approach. OPR is a form of integrated knowledge translation that blends action research and organizational learning to undertake research with organizations and improve practice [102-107]. N\&G (organization) proposed the research questions and will participate in all research steps. The NPI has OPR experience and expertise. The NPI led a CIHR-funded systematic review on OPR key processes and outcomes [107]. A steering committee composed of the NPI, the coprincipal investigator, the partner (principal knowledge user), another knowledge user (AKH), and 2 low-SES parents will meet before and after each phase for planning and interpreting results, respectively. All team members will be consulted and have the opportunity to influence the steering committee's decision making.

\section{Methodology and Methods}

A mixed-methods multiphase design will be used [108,109]. Ethical approval has been recently obtained from the institutional review board (IRB) of the Faculty of Medicine at McGill University (IRB\#A10-E69-17B). Phases 1, 3, and 4 will be informed by our theoretical model (Figure 2).

\section{Phase 1 (Objective 1): Identify Barriers and Facilitators to Use Naître et Grandir and Interact With Editors Via Information Assessment Method}

\section{Design}

We will conduct an exploratory qualitative interpretive study to have a better understanding of barriers and facilitators in using N\&G and interacting with editors via IAM [110]. Qualitative research is appropriate as it provides in-depth descriptions from the stakeholders' viewpoint and helps researchers to understand their constitutive elements and variants [111].

\section{Setting and Participants}

Participants will be 20 users and 20 nonusers of IAM and N\&G (additional participants will be recruited to achieve data saturation). First, users will be recruited among low-SES parents who indicate that they agree to be contacted when they complete an IAM questionnaire on $N \& G$ and who have used $N \& G$ and IAM at least once. $N \& G$ will send the group an invitation to participate in a research project via an email containing the 
research team's full identification and contact information. The research team will only communicate with $N \& G$ users who responded with an interest to participate in the research project via email or phone. Eligible parents will have no high school diploma and have an annual family income lower than Can $\$ 40,000$ (Quebec poverty line). Second, nonusers (10 who never used the IAM and 10 who never used $N \& G$ ) will be recruited by a principal investigator (CL) and a collaborator (GD, N\&G Director) who work with community organizations for parents with low SES.

\section{Data Collection}

A research assistant having experience in qualitative interviews with low-SES persons will conduct individual 60-min semistructured face-to-face interviews at the location of each participant's choice. In line with sociological and information studies [112,113], interviews will explore how participants experience, conceptualize, perceive, and understand aspects of $\mathrm{N} \& \mathrm{G}$ information and the IAM. The interview guide will consist of open-ended questions addressing the participants' routines in terms of internet use (both for their personal and children's development information needs), their experience in the use of IAM and N\&G's information, the facilitating aspects of $N \& G$ and IAM, perceived barriers in their experience, and suggestions to improve the N\&G website and IAM. On the basis of the theoretical model, the interview guide will be developed in a simplified language with input from team members and the steering committee. We will conduct 2 pilot interviews to ensure the questions are comprehensible for the participants. The recruited respondents will receive Can $\$ 20$ as compensation for their time. In addition to the research assistant's observation notes, interviews will be audio recorded and transcribed verbatim.

\section{Data Analysis}

Two principal investigators (PP and CL) have experience in qualitative research and 1 (CL) has experience in qualitative research with populations in situations of vulnerability. With the research assistant and a research trainee, they will read notes and interviews and meet regularly to build memos (meeting minutes with arguments for and against each analytical decision, as rigor is mainly based on researchers' reflexivity in this design [110]), case summaries, and themes (definitions and key examples) using hybrid deductive-inductive thematic analysis $[114,115]$. The research assistant will manage the analysis using specialized software (NVivo11). Themes will be derived from our theoretical model (Figure 2; deductive coding) and emerge from the data (inductive coding). Major themes will be barriers and facilitators. For each type of participant (user/nonuser), additional parents will be recruited up to saturation (no new parents' views of barrier or facilitator). Then, we will harmonize themes [116]. For each theme and definition, we will identify terms, confirm the usage of these terms in reference documents, distinguish correct from incorrect usage, and retain terms that facilitate unambiguous communication. This will lead us to classify, group, and clarify barriers and facilitators in a coherent taxonomy, which will be reviewed by team members and the steering committee. Findings will provide recommendations for improving IAM and N\&G.

\section{Phase 2 (Objective 2): Improve Naître et Grandir and Information Assessment Method}

Two team members (FL and GD) are head directors of the N\&G website and will lead this phase. Phase 1 findings will inform the production and implementation of IAM+N\&G+ (user-centered design). This version will integrate the perspectives of low-SES parents, the steering committee, research team members, and N\&G staff on how to overcome barriers and optimize facilitators. Production of this version will be planned with 2 Web editors and 2 Web engineers from the $\mathrm{N} \& \mathrm{G}$ team. According to Web engineers, 6 months is an ample time frame for production and beta testing. All necessary resources at $N \& G$ will be made available to implement IAM+N\&G+. Two half-day meetings with principal investigators and N\&G staff have been deemed sufficient to plan changes with editors and engineers. The N\&G Director stated that she will implement what will be requested by the phase 1 participants, as her mandate ( $\mathrm{N} \& \mathrm{G}$ mission) is to specifically address information needs of parents with low SES. For their part, AKH will redesign their website, integrate phase 1 results in this study, and implement IAM+.

\section{Phase 3 (Objective 3): Evaluate Use of Information Assessment Method+ Naître et Grandir+, Information Use, and Benefits}

\section{Design}

We will conduct a quantitative prospective longitudinal study to evaluate the impact of the intervention (IAM+N\&G+).

\section{Setting}

Weekly numbers of N\&G sessions and IAM ratings will be monitored over 2 years. A session starts when someone opens a Web page and ends when the person (or a relative with the same IP address) does not use the website for more than $30 \mathrm{~min}$. For each quintile of SES, data will be collected for 9 months preimplementation (IAM/N\&G) and 9 months postimplementation (IAM+N\&G+). To avoid bias related to the novelty effect, data collected in the 3 months immediately following the implementation will be excluded from the analysis. The chosen periods also ensure seasonal comparability of the collected outcome data (before and after intervention).

\section{Participants}

All N\&G readers and IAM raters across Canada will participate.

\section{Measurement}

N\&G and McGill already use Google Analytics, an objective and reliable automatic data collection of $N \& G$ readers' demographic characteristics and website use behavior (based on javascript codes in each Web page) [117-120]. IAM raters' demographic data are collected with a questionnaire (linked to an anonymized identifier). The validated IAM questionnaire [53] collects self-reported information use and subsequent expected health/well-being benefits for parents and their child. 
Table 2. Types of outcomes monitored weekly.

\begin{tabular}{|c|c|c|}
\hline Type & Outcome & Description and data source \\
\hline A1 & $N \& G^{\mathrm{a}}$ sessions & Weekly number of unique sessions (Google Analytics) \\
\hline A2 & $\mathrm{N} \& \mathrm{G}$ read & Weekly proportion of sessions with at least 1 page entirely read (Google Analytics) \\
\hline A3 & $\mathrm{IAM}^{\mathrm{b}}$ ratings & Weekly number of IAM questionnaires submitted \\
\hline B1 & $N \& G$ mediated & Weekly proportion of IAM ratings information used for the child of someone else \\
\hline B2 & N\&G used & Weekly proportion of IAM ratings information used for oneself and one's child \\
\hline $\mathrm{C}$ & Expected benefits & $\begin{array}{l}\text { Weekly proportion of IAM ratings expected health or well-being benefit for a parent and child, including at least } 1 \text { of } \\
\text { the following self-perceived benefits (IAM choices of response): improvement of the health or well-being of a child, } \\
\text { being less worried, prevention of a problem or the worsening of a problem, handling a problem, and being more confident } \\
\text { to decide something with someone else }\end{array}$ \\
\hline
\end{tabular}

${ }^{\mathrm{a}} \mathrm{N} \& \mathrm{G}$ : Naître et grandir.

bIAM: Information Assessment Method.

\section{Outcomes}

In line with CIHR knowledge translation guidance [54], 3 types of outcomes will be considered weekly (Table 2): (A) N\&G and IAM use, (B) self-reported N\&G information use, and (C) subsequent expected benefits.

\section{Covariates}

The main predictor will be participants' SES as determined by the Quebec Index of Material and Social Deprivation, a validated ecological measure of the (education, income, and employment) disadvantage of a given geographic area (postal code) $[121,122]$. For each session, an index will be automatically assigned using (1) the reported postal code and the Canadian Deprivation Index Assignment Program (CDIAP) of the Public Health Agency of Canada when the data source is IAM and (2) the postal code matched to the session geotag via the "Dissemination Area Boundary File" of Statistics Canada and the CDIAP when the data source is Google Analytics. This will allow for the identification of low-SES participants (highest quintile of material and social deprivation). Using Google Analytics, participants' demographic variables that will be considered in all analyses are age, gender, rural/urban location, and province. In addition, Web page-specific variables will be included to assess potential confounding and effect modifications. For each session, the type of device (Google Analytics: phone, tablet or laptop, and desktop), the audio-guide use (Google Analytics: yes or no), and the readability score of pages entirely read (automatic extraction and measurement using a text classifier validated for French) [123] will be collected.

\section{Study Size}

On the basis of our 2-year pilot data (2014/09-2016/08), we anticipate about 5 million N\&G sessions and 15,000 IAM ratings from Canadian participants during each period (pre- and postimplementation).

\section{Anticipated Results}

The IAM+N\&G+ will result in an increase of all outcomes ( $N \& G$ and IAM use, self-reported $N \& G$ information use, and subsequent expected health and well-being benefits for parents and children such as decreased worries and health improvement, respectively).

\section{Statistical Analysis}

Linear mixed modeling will integrate spatial analytics (geomatics) and account for the clustered nature of the data. The pre/post status, the SES quintile of deprivation, and potentially confounding variables will be included as fixed-effects covariates. The inference model will incorporate random effect terms for individual variables and Web page-specific variables. For each outcome, an interaction term of the SES quintile of deprivation and the pre/post status will be included to assess the pre/post change for each quintile. Estimated regression coefficients and variance parameters will be reported along with appropriate confidence intervals.

\section{Phase 4(Objective 4): Describe Parent and Child Outcomes of Naître et Grandir+ Information Use}

\section{Design}

We will conduct a qualitative interpretive study to generate an in-depth description of parent and child outcomes from the parents' perspective [124]. On the basis of our systematic review [66,67], we anticipate 3 types of parent outcomes (decreased worries, increased confidence, and self-management) and 2 types of child outcomes (prevented problem and improved development, health, and well-being). Our pilot data (34,021 IAM ratings) also suggest parents rarely report potential negative consequences of using information, for example, vaccine adverse effect $(n=183 ; 0.5 \%)$. In outcomes research, qualitative methods are appropriate for exploring complex outcomes from the stakeholders' perspective, such as life experiences [111,125-131]. In our study, information can influence parent decision making, but the relationship between information and decision is not simple. Our qualitative study will (1) identify causal events, (2) map them in a complex causal network, and (3) build a chronological chain of qualitative evidence between $\mathrm{N} \& \mathrm{G}$ information and a parents' decision that affects knowledge, attitude, or behavior [131,132].

\section{Participants}

Participants who received the N\&G+ newsletter, used IAM+ at least once, have agreed to be contacted for research, and live in a high deprivation area will be approached for recruitment. The recruitment procedure will be the same as for phase 1. In 2015, more than 24,000 families received, upon request, the weekly 
newsletter. We will begin by recruiting 30 parents (and continue recruitment, as needed, to achieve data saturation) who report, via IAM+, positive health and well-being outcomes and/or potential negative consequences of information (prioritizing those who live in the areas of highest deprivation). As we are looking for individual stories for about 6 types of outcomes (some less frequently reported than others), data saturation may not be reached with fewer than 50 participants [111,133-135].

\section{Data Collection}

The research assistant having experience in qualitative interviews with low-SES persons will conduct 60-min face-to-face interviews to elicit participants' IAM+ ratings. The interview guide will be based on our theoretical model (Figure 2 ) and input from team members and the steering committee. To stimulate recall (memory), the interviewee will be given the list of recent texts they rated and their ratings. For each newsletter, the research assistant will ask open questions regarding what happened to them and/or their children that led them to report an expected outcome (positive or negative). Participants will be interviewed twice 3 months apart to increase the number of described outcomes and avoid fatigue of long interviews. Participants will receive Can \$20 per interview as compensation for their time. In addition to the research assistant's observation notes, interviews will be audio recorded and transcribed verbatim.

\section{Data Analysis}

Two principal investigators (PP and CL) have experience in qualitative research. With the research assistant, a collaborator anthropologist having expertise in life histories (MB) and a research trainee will read notes and interviews and meet regularly. For each case (information used with at least 1 outcome experienced by a parent and a child), they will interpret the data in the form of a small story [112,136-138]. This method allows researchers to describe a person's individual experience (including all perceived influences) and helps the researcher understand the individual's attitude and behavior [33]. In research meetings, 2 questions will be answered through recorded discussion of arguments for and against each analytical decision (rigor based on sharing reflexivity): is the case story clear? and are the causal network and chain of evidence trustworthy? Disagreements about clarity and trustworthiness of case stories will be resolved with 3 other team members having experience in qualitative research (Bouthillier, Thoër, and Smythe). Case stories will be reviewed by all team members and the steering committee. This may detect issues and result in the principal investigators and research assistant revising parts of their analysis.

\section{Anticipated Results}

This will generate up to 10 case stories per outcome type, being the first in-depth qualitative description of low-SES parents' perspective on outcomes of online child information use.

\section{Results}

The project was funded in 2017 by the CIHR and received an ethics approval by the McGill University's IRB. Data collection for phase 1 was completed in 2018. Phases 2 to 4 will be completed by 2020 . Findings from this study will be used to develop a free toolkit, useful to all Web editors, with recommendations for improving health information for low-SES persons and interactions with them using IAM. Results will be published in peer-reviewed journals and presented at national and international scientific conferences.

\section{Discussion}

\section{Direct Impact on Naître et grandir and AboutKidsHealth}

Any improvement of knowledge translation tools and websites such as IAM, N\&G, and AKH can have an important impact as it affects a large population of individuals with a low literacy level. In fact, the effectiveness of childhood education interventions has been demonstrated repeatedly [16-19,23,27-47]. In our 2-year pilot data, parents expected health and well-being benefits (for themselves or their child) from using $\mathrm{N} \& \mathrm{G}$ information in $65.4 \%$ of all IAM ratings $(n=34,021)$ [50]. In accordance with knowledge translation and implementation research [62], we will not replicate effectiveness studies and rather focus on improving interventions that work.

Our project can improve engagement (number of visits) with websites providing high-quality low literacy information; in turn, online parenting information improves parents' knowledge, attitudes, and behaviors [139-145]. Given our integrated knowledge translation (participatory research) approach, N\&G and AKH will adapt their content for low-SES users as we generate results. In addition, IAM+ will better support low-SES parents' interactions with Web editors and empowerment. Thus, our results can immediately benefit millions of information users with a low literacy level (children's parents and relatives), for example, in Canada (Table 3).

$\mathrm{IAM}+\mathrm{N} \& \mathrm{G}+$ can be seen as an innovative intervention that complements traditional literacy programs (eg, family literacy classes). Indeed, interventions that somewhat compensate for a low literacy level can greatly improve parents' and children's health and well-being [23]. Thus, our results can have a positive impact on $55 \%$ of the Canadian working age, those who have a low level of health literacy and need compensatory help to manage their health $[23,89,90]$.

Specifically, IAM+N\&G+ can help Canadians in francophone minority communities, as 500,000 annual N\&G website visits originate from them. Research with these communities is very underfunded, thus a CIHR priority [146]. As stated in the October 2016 report of the Commissioner of Official Languages [147], early childhood development in these communities is hindered by a lack of resources, and the absence of specific funding has left them vulnerable and often incapable of meeting their needs. 
Table 3. Targeted population in Canada.

\begin{tabular}{|c|c|c|}
\hline Across Canada & IAM $^{\mathrm{a}}$ Naître et grandir (new version) & IAM AboutKidsHealth (new version) \\
\hline Families ${ }^{b}$ & $\begin{array}{l}1.3 \text { million families have French as mother tongue (cou- } \\
\text { ples with children and single-parent families with at least } \\
1 \text { child) }\end{array}$ & $\begin{array}{l}5.8 \text { million families (couples with children and single- } \\
\text { parent families with at least } 1 \text { child)_all languages }\end{array}$ \\
\hline Children's parents and relatives ${ }^{b}$ & $\begin{array}{l}2.8 \text { million adults aged } 20 \text { to } 69 \text { years have a low literacy } \\
\text { level (and French as mother tongue) }\end{array}$ & $\begin{array}{l}12 \text { million adults aged } 20 \text { to } 69 \text { years have a low liter- } \\
\text { acy level }\end{array}$ \\
\hline Website visits from Canada & $\begin{array}{l}8.3 \text { million }^{\mathrm{c}} \text { visits in } 2015 \text { mainly from Quebec }(7.8 \text { mil- } \\
\text { lion), Ontario }(304,000) \text {, and New Brunswick }(70,000)\end{array}$ & $\begin{array}{l}1.5 \text { million visits in } 2015 \text { mainly on Web pages in } \\
\text { English }(58 \%) \text {, French }(16 \%) \text {, Spanish }(14 \%) \text {, and } \\
\text { Arabic }(5 \%)\end{array}$ \\
\hline
\end{tabular}

aAM: Information Assessment Method.

${ }^{\mathrm{b}}$ Statistics Canada 2015.

${ }^{\mathrm{c}} 76 \%$ of parents of children aged under 8 years consult Naître et grandir in Quebec (on average 1.3 times per week).

\section{Potential Impact Beyond Naître et grandir and AboutKidsHealth}

Results will inform the development of an open access online tool kit on how to adapt websites and IAM+ for a low literacy audience (a growing consideration of many Web editors). The tool kit will be designed to be generalizable to all types of online consumer health information in Canada. It will include guidance with 3 main messages: (1) how to produce simple information in lay language with audio and visual content, (2) how to better interact with low-SES persons using IAM+, and (3) how to use consumers' IAM+ ratings and feedback to continuously optimize information content. The tool kit will be freely available to any Web editor via the Quebec SPOR-SUPPORT Unit and IAM websites. The NPI has experience in developing tools and leads the method development platform of the Quebec SPORSUPPORT Unit.

Our primary knowledge translation goal for knowledge user audiences will be to raise awareness about our main messages and drive attention to the tool kit. A secondary knowledge translation goal will be to support the implementation of the toolkit by Web editors. Knowledge users will disseminate our work in multiple Canadian organizations. As per reviews on scaling up [148-150], we will update our 2016 environmental scan and contact all Canadian websites targeting parents. A specialized librarian (collaborator) will reach additional health websites through librarian listservs and peer networks. Team members will raise general awareness for the tool kit and deliver our main messages to a variety of academic and nonacademic knowledge user audiences via a range of knowledge translation strategies (conference presentations, open access peer-reviewed publications, plain language summaries and grey literature, social media, and networks). Multiple knowledge translation channels will be used including Twitter (@UniteSoutien) and websites such as the Quebec SPOR-SUPPORT Unit and the IAM websites [151,152].

\section{Contribution to Scientific Knowledge}

Our project will advance knowledge on the value of online information for, and interaction with, low-SES persons to strengthen health systems. On the one hand, this project is the first to systematically explore health and well-being outcomes for low-SES parents and children associated with parenting information websites. Most studies focus on discussion forums that can be intimidating to low-SES parents $[140,142,143,153,154]$. On the other hand, many studies concern relational marketing and website feedback buttons [52,155-158], but we know of none that addresses interactions between low-SES persons and Web editors (such as interaction through IAM+).

\section{Timeline and Potential Challenges}

Overall, 3 years will be needed to complete this project (Figure 3 ). Our phases are simple and well defined, and our planning is realistic. In phases 1 and 4, we anticipate no recruitment difficulties. Many parents have already agreed to be contacted for research, and N\&G will facilitate the recruitment. Phase 2 is feasible, and the deliverables are realistic given that $\mathrm{N} \& \mathrm{G}$ has already implemented IAM, McGill and N\&G have a strong OPR partnership, and $N \& G$ is committed to implementing IAM+N\&G+. In phase 3 , the large number of $N \& G$ readers guarantee a large sample. To control for potential seasonal variation in the number of sessions pre- and postimplementation, monitoring will be conducted during the same seasons. To control for contextual changes, variables such as type of device, age, gender, and location are covariates. We have opted for a prospective longitudinal study as monitoring is embedded in $\mathrm{N} \& \mathrm{G}$ routines. In addition, although randomization would provide a higher level of evidence, it was considered unethical to randomly assign low-SES parents to N\&G+ or N\&G information and impractical for such a popular website (contamination bias) [159]. Moreover, 3 typical potential sources of biases in longitudinal designs may not affect our study: the use of proportions will control for historical events, there will be no respondent fatigue as our 2-year pilot data showed that the monthly number of IAM raters is stable, and the social desirability bias will affect pre- and postimplementation periods in a similar manner. 
Figure 3. Study timeline. N\&G: Naître et grandir; KT: knowledge translation; IAM: Information Assessment Method.

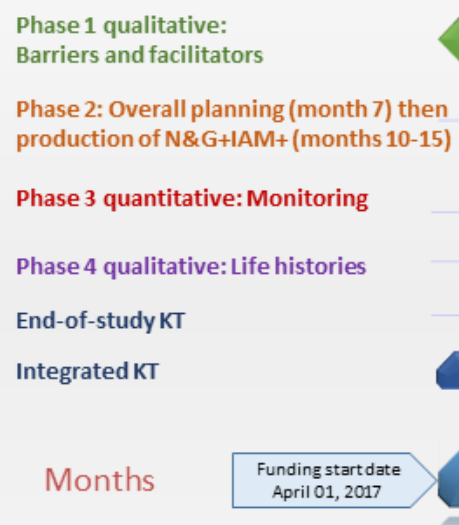

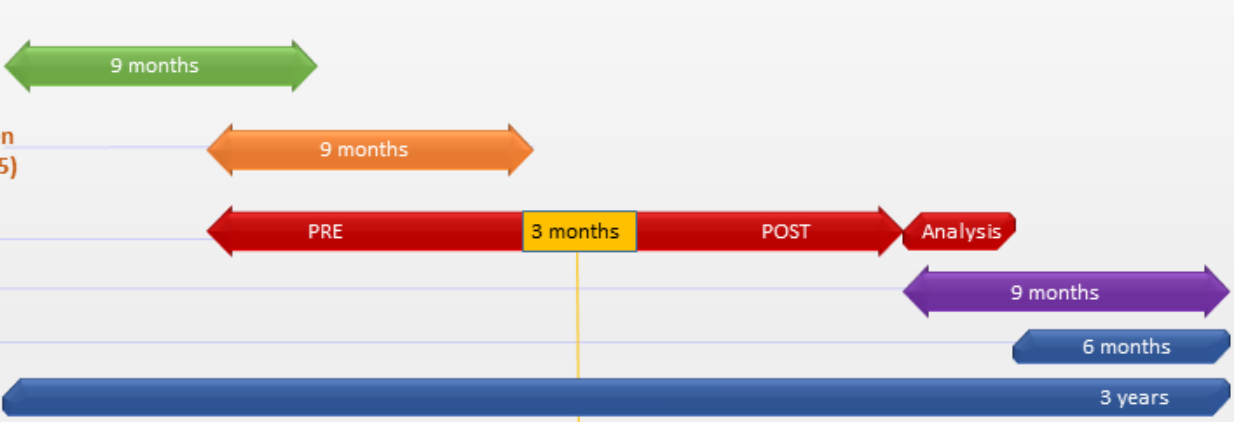

IAM+N\& \&+ implemented at the beginning (data not analyzed: novelty effect)

\begin{tabular}{|l|l|l|l|l|l|l|l|l|l|l|l|}
\hline $1-3$ & $4-6$ & $7-9$ & $10-12$ & $13-15$ & $16-18$ & $19-21$ & $22-24$ & $25-27$ & $28-30$ & $31-33$ & $34-36$ \\
\hline
\end{tabular}
Considering the commitment, expertise, and networks of our team, we expect no major challenges. This project is highly facilitated by the participatory research approach (a form of integrated knowledge translation). In addition, it is sustainable as our results will be applied and sustained by 2 longstanding organizations. N\&G is fully funded since 1998 by the Lucie et André Chagnon Foundation (one of the largest philanthropic agencies in Canada) and is a priority of this foundation. AKH is owned by the Hospital for Sick Children (Toronto) and is fully funded since 2004 by multiple maternal and child health agencies.

\section{Conclusions}

The results of this study will provide a deep understanding of how low-SES parents use online child information and interact with Web editors. Following the implementation of IAM+N\&G+, results will also elucidate subsequent health outcomes for low-SES parents and children after interaction with Web editors have been optimized. Thus, our results can immediately benefit millions of information users, children's parents and relatives in particular, with a low literacy level.

\section{Acknowledgments}

The authors wish to thank Dr Suzanne Smythe (Simon Fraser University, Canada), Mr Sean Schurr (AboutKidsHealth, Canada), Maria de Carmen Reyes (Centro de Investigación en Geografía y Geomática, Mexico), and Ms Catherine Chouinard (Avenir d'enfants, Canada) for their collaboration in developing this proposal. N\&G is funded by the philanthropic organization "Fondation Lucie et André Chagnon.” PP holds an investigator salary award from the Fonds de recherche en santé du Québec. This study has been funded by the CIHR (\#PJT153200).

\section{Conflicts of Interest}

None declared.

\section{References}

1. Marmot MG. Understanding social inequalities in health. Perspect Biol Med 2003 Jan;46(3 Suppl):S9-23. [doi: 10.1353/pbm.2003.0070] [Medline: 14563071]

2. Whitehead M. A typology of actions to tackle social inequalities in health. J Epidemiol Community Health 2007 Jun;61(6):473-478 [FREE Full text] [doi: 10.1136/jech.2005.037242] [Medline: 17496254]

3. Bardsley M, Morgan D. Inequalities in maternal and early child health: Priorities for London. Measuring Inequalities in the Health of Mothers and Children. Briefing Paper 1. London: Department of Health; 2000.

4. Siegrist J, Marmot M, editors. Social inequalities in health. Oxford: Oxford University Press; 2006.

5. Warwick-Booth L. Social inequality. London: Sage; 2013.

6. Grabb E, Guppy N. Social inequality in Canada. Don Mills: Pearson Prentice Hall; 2008.

7. Brooks-Gunn J, Duncan GJ. The effects of poverty on children. Future Child 1997;7(2):55-71. [Medline: 9299837]

8. McLeod J, Shanahan MJ. Poverty, parenting, and children's mental health. Am Sociol Rev 1993 Jun;58(3):351-366. [doi: $\underline{10.2307 / 2095905]}$

9. Curtis LJ, Dooley MD, Lipman EL, Feeny DH. The role of permanent income and family structure in the determination of child health in Canada. Health Econ 2001 Jun;10(4):287-302. [doi: 10.1002/hec.591] [Medline: 11400252]

10. Michl LC, Handley ED, Rogosch F, Cicchetti D, Toth SL. Self-criticism as a mechanism linking childhood maltreatment and maternal efficacy beliefs in low-income mothers with and without depression. Child Maltreat 2015 Nov;20(4):291-300 [FREE Full text] [doi: 10.1177/1077559515602095] [Medline: 26318693] 
11. Health Inequalities Unit. Tackling health inequalities. London: Department of Health; 2008. URL: http://webarchive. nationalarchives.gov.uk/20031221005110/http://www.doh.gov.uk/healthinequalities/programmeforaction/programmeforaction. pdf [WebCite Cache ID 736bzNftU]

12. Raphael D. Poverty, income inequality, health in Canada. In: Social determinants of health: Canadian perspectives. Toronto: Canadian Scholars' Press; 2016:218-239.

13. Bennett IM, Chen J, Soroui JS, White S. The contribution of health literacy to disparities in self-rated health status and preventive health behaviors in older adults. Ann Fam Med 2009;7(3):204-211 [FREE Full text] [doi: 10.1370/afm.940] [Medline: 19433837]

14. Easton P, Entwistle V, Williams B. Health in the 'hidden population' of people with low literacy. A systematic review of the literature. BMC Public Health 2010 Aug 05;10:459 [FREE Full text] [doi: 10.1186/1471-2458-10-459] [Medline: 20687946]

15. Institute of Medicine. Health literacy. Washington: The National Academy Press; 2004.

16. Canadian Council on learning. Health literacy in Canada. Ottawa: Canadian Council on Learning; 2008.

17. Rootman I, Gordon-El-Bihbety D. A vision for a health literate Canada. Ottawa: Canadian Public Health Association; 2008.

18. Smith S, Duman M. The state of consumer health information: an overview. Health Info Libr J 2009 Dec;26(4):260-278 [FREE Full text] [doi: 10.1111/j.1471-1842.2009.00870.x] [Medline: 19930474]

19. Clement S, Ibrahim S, Crichton N, Wolf M, Rowlands G. Complex interventions to improve the health of people with limited literacy: a systematic review. Patient Educ Couns 2009 Jun;75(3):340-351. [doi: 10.1016/j.pec.2009.01.008] [Medline: 19261426$]$

20. Benigeri M, Pluye P. Shortcomings of health information on the internet. Health Promot Int 2003 Dec;18(4):381-386. [Medline: 14695369$]$

21. Or C, Karsh BT. A systematic review of patient acceptance of consumer health information technology. J Am Med Inform Assoc 2009;16(4):550-560 [FREE Full text] [doi: 10.1197/jamia.M2888] [Medline: 19390112]

22. Weightman AL, Morgan HE, Shepherd MA, Kitcher H, Roberts C, Dunstan FD. Social inequality and infant health in the UK: systematic review and meta-analyses. BMJ Open 2012;2(3) [FREE Full text] [doi: 10.1136/bmjopen-2012-000964] [Medline: 22700833]

23. McNichol BR, Rootman I. Literacy and Health Literacy: New Understandings about Their Impact on Health. In: Raphael D, editor. Social Determinants of Health: Canadian Perspectives. Toronto: Canadian Scholars' Press; 2016:261-290.

24. Feinstein L, Sabates R, Anderson T, Sorhaindo A, Hammond C. What are the effects of education on health? 2006 Presented at: Symposium Measuring Effects of Education on Health; March 23-25, 2006; Copenhagen URL: http://www.oecd.org/ education/innovation-education/37425753.pdf

25. Mikkonen J, Raphael D. Social determinants of health: The Canadian facts. Toronto, Canada: York University School of Health Policy and Management; 2010.

26. Case D. Looking for information. London: Academic Press; 2002.

27. Lloyd A, Anne Kennan M, Thompson K, Qayyum A. Connecting with new information landscapes: information literacy practices of refugees. J Doc 2013 Jan 11;69(1):121-144. [doi: 10.1108/00220411311295351]

28. Knapp C, Madden V, Wang H, Sloyer P, Shenkman E. Internet use and eHealth literacy of low-income parents whose children have special health care needs. J Med Internet Res 2011 Sep 29;13(3):e75 [FREE Full text] [doi: 10.2196/jmir.1697] [Medline: 21960017]

29. Hersberger J. Are the economically poor information poor? Does the digital divide affect the homeless and access to information? Can J Inform Lib Sci 2003;27(3):45-63 [FREE Full text]

30. Chatman EA. The impoverished life-world of outsiders. J Am Soc Inf Sci 1996 Mar;47(3):193-206. [doi: 10.1002/(SICI)1097-4571(199603)47:3<193::AID-ASI3>3.0.CO;2-T]

31. Britz JJ. To know or not to know: a moral reflection on information poverty. J Inf Sci 2016 Jul;30(3):192-204. [doi: $10.1177 / 0165551504044666]$

32. Zamaria C, Fletcher F. Canada online! : the internet, media and emerging technologies : uses, attitudes, trends and international comparisons, year two highlights, 2007. Toronto: Ryerson University; 2008.

33. Baker DW, Wolf MS, Feinglass J, Thompson JA, Gazmararian JA, Huang J. Health literacy and mortality among elderly persons. Arch Intern Med 2007 Jul 23;167(14):1503-1509. [doi: 10.1001/archinte.167.14.1503] [Medline: 17646604]

34. Coulter A. Patient engagement--what works? J Ambul Care Manage 2012;35(2):80-89. [doi: 10.1097/JAC.0b013e318249e0fd] [Medline: 22415281]

35. Dwyer D, Liu H. The impact of consumer health information on the demand for health services. Q Rev Econ Fin 2013 Feb;53(1):1-11. [doi: 10.1016/j.qref.2012.11.002]

36. Edwards M, Davies M, Edwards A. What are the external influences on information exchange and shared decision-making in healthcare consultations: a meta-synthesis of the literature. Patient Educ Couns 2009 Apr;75(1):37-52. [doi: 10.1016/j.pec.2008.09.025] [Medline: 19036550]

37. Kickbusch I. Health literacy: addressing the health and education divide. Health Promot Int 2001 Sep;16(3):289-297. [Medline: $\underline{11509466]}$ 
38. Lee CJ. Does the internet displace health professionals? J Health Commun 2008;13(5):450-464. [doi: 10.1080/10810730802198839] [Medline: 18661387]

39. Parsons S, Winterbottom A, Cross P, Redding D. The quality of patient engagement and involvement in primary care. London: The King's Fund; 2010. URL: https://www.picker.org/wp-content/uploads/2014/10/

The-quality-of-patient-engagement...-primary-care.pdf[WebCite Cache ID 736evLhiM]

40. Renahy E, Chauvin P. Internet uses for health information seeking: a literature review. Rev Epidemiol Sante Publique 2006 Jun;54(3):263-275. [Medline: 16902386]

41. Wasson JH, Forsberg HH, Lindblad S, Mazowita G, McQuillen K, Nelson EC. The medium is the (health) measure: patient engagement using personal technologies. J Ambul Care Manage 2012;35(2):109-117. [doi: 10.1097/JAC.0b013e31824a235e] [Medline: 22415284]

42. Wagner TH, Hu TW, Hibbard JH. The demand for consumer health information. J Health Econ 2001 Nov;20(6):1059-1075. [Medline: 11758048]

43. Tu HT, Cohen GR. Striking jump in consumers seeking health care information. Track Rep 2008 Aug(20):1-8. [Medline: 18770913]

44. Fox S, Duggan M. Health Online 2013. Washington, DC: Pew Research Center; 2013. URL: http://www.pewinternet.org/ 2013/01/15/health-online-2013/[WebCite Cache ID 736f9FLiv]

45. Coker TR, Windon A, Moreno C, Schuster MA, Chung PJ. Well-child care clinical practice redesign for young children: a systematic review of strategies and tools. Pediatrics 2013 Mar;131(Suppl 1):S5-25 [FREE Full text] [doi: 10.1542/peds.2012-1427c] [Medline: 23457149]

46. Suziedelyte A. How does searching for health information on the internet affect individuals' demand for health care services? Soc Sci Med 2012 Nov;75(10):1828-1835. [doi: 10.1016/j.socscimed.2012.07.022] [Medline: 22884947]

47. Korenstein D, Falk R, Howell EA, Bishop T, Keyhani S. Overuse of health care services in the United States: an understudied problem. Arch Intern Med 2012 Jan 23;172(2):171-178. [doi: 10.1001/archinternmed.2011.772] [Medline: 22271125]

48. Naitre et grandir. URL: https://naitreetgrandir.com [accessed 2018-10-05] [WebCite Cache ID 72wohsIAW]

49. Pluye P, Granikov V, Bartlett G, Grad RM, Tang DL, Johnson-Lafleur J, et al. Development and content validation of the information assessment method for patients and consumers. JMIR Res Protoc 2014 Feb 18;3(1):e7 [FREE Full text] [doi: 10.2196/resprot.2908] [Medline: 24550180]

50. Pluye P, Sherif RE, Bartlett G, Granikov V, Grad RM, Doray G, et al. Perceived outcomes of online parenting information according to self-selected participants from a population of website users. Proc Assoc Info Sci Tech 2016 Feb 24;52(1):1-3. [doi: 10.1002/pra2.2015.145052010072]

51. Pluye P, El SR, Doray G. Santepop. 2015. [Evaluating the information of being born and growing up by parents] URL: https://www.santepop.qc.ca/fr/posts/rapport-devenement/levaluation-des-informations-de-naitre-et-grandir-par-les-parents [accessed 2018-10-12] [WebCite Cache ID 736fX6npn]

52. Sherif RE, Roy P, Tang D, Pluye P, Bush P, Doray G, et al. Toward an information management system for handling parenting information users' comments. In: Proc Assoc Info Sci Tech. 2016 Feb 24 Presented at: Annual Meeting of the Association for Information Science and Technology; November 6-10, 2015; St-Louis p. 1-3. [doi: 10.1002/pra2.2015.145052010076]

53. Bujold M, El SR, Bush P, Johnson-Lafleur J, Doray G, Pluye P. Ecological content validation of the Information Assessment Method for parents (IAM-parent): a mixed methods study. Eval Program Plann 2018 Dec;66:79-88 [FREE Full text] [doi: 10.1016/j.evalprogplan.2017.09.011] [Medline: 29053984]

54. Monitoring Knowledge Use and Evaluating Outcomes of Knowledge Use. Canadian Institute for Health Research (CIHR); 2018. URL: http://www.cihr-irsc.gc.ca/e/41945.html[WebCite Cache ID 72wrSxbMe]

55. van Dijk JA. Digital divide research, achievements and shortcomings. Poetics 2006 Aug;34(4-5):221-235. [doi: 10.1016/j.poetic.2006.05.004]

56. van Deursen AJ, van Dijk JA, ten Klooster PM. Increasing inequalities in what we do online: a longitudinal cross sectional analysis of Internet activities among the Dutch population (2010 to 2013) over gender, age, education, and income. Telemat Inform 2015 May;32(2):259-272. [doi: 10.1016/j.tele.2014.09.003]

57. Hargittai E. The digital reproduction of inequality. In: Grusky D, editor. Social stratification. Boulder, CO: Westview Press; 2008:936-944.

58. DiMaggio P, Hargittai E. From the 'Digital Divide' to 'Digital Inequality'. Princeton: Woodrow Wilson School, Princeton University; 2001. URL: https://culturalpolicy.princeton.edu/sites/culturalpolicy/files/wp15 dimaggio hargittai.pdf $[$ WebCite Cache ID 736gLD1iW]

59. Neter E, Brainin E. eHealth literacy: extending the digital divide to the realm of health information. J Med Internet Res 2012 Jan 27;14(1):e19 [FREE Full text] [doi: 10.2196/jmir.1619] [Medline: 22357448]

60. Chang BL, Bakken S, Brown SS, Houston TK, Kreps GL, Kukafka R, et al. Bridging the digital divide: reaching vulnerable populations. J Am Med Inform Assoc 2004;11(6):448-457 [FREE Full text] [doi: 10.1197/jamia.M1535] [Medline: 15299002]

61. Lavoie A, Fontaine C. [Getting to know parents better in Quebec: A portrait from the 2015 Survey of Parents of Children 0-5 Years of Age]. 2016. URL: http://www.stat.gouv.qc.ca/statistiques/conditions-vie-societe/environnement-familial/ eqepe.pdf $[$ WebCite Cache ID 736gbhQPC] 
62. Knowledge Translation.: Canadian Institute for Health Research (CIHR); 2018. URL: http://www.cihr-irsc.gc.ca/e/29418. html[WebCite Cache ID 72ws2I6Ne]

63. Graham ID, Logan J, Harrison MB, Straus SE, Tetroe J, Caswell W, et al. Lost in knowledge translation: time for a map? J Contin Educ Health Prof 2006;26(1):13-24. [doi: 10.1002/chp.47] [Medline: 16557505]

64. Pluye P, Grad R, Repchinsky C, Dunikowski L, Frati F, Shohet L, et al. In primary health care, what are the outcomes associated with the use of online consumer health information? A participatory systematic mixed studies review protocol. 2014. URL: http://www.crd.york.ac.uk/PROSPERO/display_record.php?ID=CRD42014009738[WebCite Cache ID 736gud9zE]

65. Granikov V, Sherif R, Pluye P. Patient information aid: promoting the right to know, evaluate, and share consumer health information found on the internet. J Consum Health Internet 2015 Nov 24;19(3-4):233-240. [doi: $10.1080 / 15398285.2015 .1094302]$

66. El Sherif R, Pluye P, Granikov V. What are the outcomes associated with the use of online consumer health information in primary health care? A systematic review with framework synthesis of quantitativequalitative evidence. 2016 Presented at: Mixed Methods International Research Association (MMIRA) Annual Conference; August 3-5, 2016; Durham, UK.

67. Granikov V, El Sherif R, Tang D. What are the outcomes associated with the use of online consumer health information in primary health care? A systematic review with framework synthesis of quantitative and qualitative evidence abstract. $\mathrm{J}$ Can Health Libr Assoc 2016;35(2):96-110.

68. Booth A, Carroll C. How to build up the actionable knowledge base: the role of 'best fit' framework synthesis for studies of improvement in healthcare. BMJ Qual Saf 2015 Nov;24(11):700-708 [FREE Full text] [doi: 10.1136/bmjqs-2014-003642] [Medline: 26306609]

69. Carroll C, Booth A, Leaviss J, Rick J. 'Best fit' framework synthesis: refining the method. BMC Med Res Methodol 2013 Mar 13;13:37 [FREE Full text] [doi: 10.1186/1471-2288-13-37] [Medline: 23497061]

70. Pluye P, Grad R, Repchinsky C, Jovaisas B, Johnson-Lafleur J, Carrier ME, et al. Four levels of outcomes of information-seeking: a mixed methods study in primary health care. J Am Soc Inf Sci Tec 2012 Dec 10;64(1):108-125. [doi: 10.1002/asi.22793]

71. Fisher K, Landry C, Naumer C. Social spaces, casual interactions and meaningful exchanges. Inf Res 2007 Jan;12(2) [FREE Full text]

72. Wilson TD. On user studies and information needs. J Doc 2006 Nov;62(6):658-670. [doi: 10.1108/00220410610714895]

73. Dervin B, Nilan M. Information needs and uses. Annu Rev Inf Sci Technol 1986;21:3-33 [FREE Full text]

74. Dervin B. Human studies and user studies: A call for methodological inter-disciplinarity. Inf Res 2003;9(1) [FRE Full text]

75. Courtright C. Context in information behavior research. Ann Rev Info Sci Tech 2008 Oct 24;41(1):273-306. [doi: 10.1002/aris.2007.1440410113]

76. Renahy E, Cadot E, Roustit C, Parizot I, Chauvin P. [Searching for health information on the Internet: A contextual analysis of SIRS data, a Parisian cohort]. 2010. URL: https://www.cairn.info/revue-sante-publique-2009-hs2-page-27.htm[WebCite Cache ID 736j4aw2S]

77. Savolainen R. Information behavior and information practice: reviewing the "Umbrella Concepts" of information - seeking studies. Libr Q 2007 Apr;77(2):109-132. [doi: 10.1086/517840]

78. Saracevic T, Kantor P. Studying the value of library and information services. Part I. Establishing a theoretical framework. J Am Soc Inf Sci 1997 Jun;48(6):527-542. [doi: 10.1002/(SICI)1097-4571(199706)48:6<527::AID-ASI6>3.0.CO;2-W]

79. van Deursen AJ, van Dijk JA. Toward a multifaceted model of internet access for understanding digital divides: an empirical investigation. Inform Soc 2015 Sep 11;31(5):379-391. [doi: 10.1080/01972243.2015.1069770]

80. Zach L, Dalrymple PW, Rogers ML, Williver-Farr H. Assessing internet access and use in a medically underserved population: implications for providing enhanced health information services. Health Info Libr J 2012 Mar;29(1):61-71 [FREE Full text] [doi: 10.1111/j.1471-1842.2011.00971.x] [Medline: 22335290]

81. Yu L. Understanding information inequality: making sense of the literature of the information and digital divides. $\mathrm{J}$ Librarianship Inf Sci 2016 Jun 30;38(4):229-252. [doi: 10.1177/0961000606070600]

82. Luhmann N. What is communication? Commun Theory 1992 Aug;2(3):251-259. [doi: 10.1111/j.1468-2885.1992.tb00042.x]

83. Luhmann N, Bednarz J, Baecker D. Social Systems. Redwood City, California: Stanford University Press; 1996.

84. Luhmann N. [Politics and complexity: The contributions of the general theory of systems]. Paris: Les Éditions du Cerf; 1999.

85. Luhmann N. [Legitimation through the procedure]. Québec: Les Presses de l'Université Laval; 2001.

86. Anderson M, Perrin A. 13\% of Americans don't use the internet: Who are they?. 2018 Mar 05. URL: http://www. pewresearch.org/fact-tank/2018/03/05/some-americans-dont-use-the-internet-who-are-they/[WebCite Cache ID 72wt4rUwN]

87. Chalifoux E. Léger Recherche Stratégie Conseil. Les aspirations des Québécois en matière de politiques sociales. Montréal: Foundation Lucie et André Chagnon; 2015.

88. SOM Recherche \& Sondages. Évaluation de l'impact du site et du magazine Naître et Grandir (personal communication). Montréal: Naître et grandir; 2015. 
89. Organisation for Economic Co-operation and Development (OECD). Income Distribution Database. Paris: OECD; 2015. URL: http://www.oecd.org/social/income-distribution-database.htm[WebCite Cache ID 736kaPHiS]

90. Organisation for Economic Co-operation Development (OECD). The Survey of Adult Skills: Reader's Companion [PIAAC survey volume 2 on methodology and methods]. Paris: OECD Publishing; 2013.

91. Nahl D, Bilal D. Information and emotion: The emergent affective paradigm in information behavior research and theory. Medford: Information Today Inc; 2007.

92. Nahl D. Social-biological information technology: an integrated conceptual framework. J Am Soc Inf Sci 2007 Nov;58(13):2021-2046. [doi: 10.1002/asi.20690]

93. Anderson M, Perrin A. Pewresearch. 2018 Mar 05. 13\% of Americans don't use the internet: Who are they? URL: http:/ /www.pewresearch.org/fact-tank/2018/03/05/some-americans-dont-use-the-internet-who-are-they/ [accessed 2018-10-05] [WebCite Cache ID 72wt4rUwN]

94. AboutKidsHealth. URL: https://www.aboutkidshealth.ca/ [accessed 2018-10-05] [WebCite Cache ID 72wu5R7wO]

95. Burris B. Computerization of the workplace. Annu Rev Sociol 1998 Aug;24:141-157. [doi: 10.1146/annurev.soc.24.1.141]

96. DiMaggio P, Hargittai E, Neuman W, Robinson J. Social implications of the internet. Annu Rev Sociol 2001 Aug;27:307-336. [doi: 10.1146/annurev.soc.27.1.307]

97. Romanow R. Building on Values: The Future of Health Care in Canada. Saskatoon: Commission on the Future of Health Care in Canada; 2002.

98. Commission Clair, Commission d'étude sur les services de santé et les services sociaux. Les solutions émergentes: Rapport et recommandations. Québec: Ministère de la santé et des services sociaux; 2000.

99. World Summit on the Information Society (WSIS). tjsl.edu. Geneva: United Nations; 2005. Tunis agenda for the information society URL: https://www.tjsl.edu/slomansonb/5.2 TunisAgenda.pdf [accessed 2018-10-12] [WebCite Cache ID 736sX4t5Y]

100. Industry Canada. Canada at the World Summit on the Information Society (WSIS). Government of Canada 2009.

101. Centre francophone d'informatisation des organisations (CEFRIO). Génération A: Portrait de l'utilisation d'internet et de l'ordinateur par les aînés internautes du Québec. Montréal: CEFRIO; 2011.

102. Waterman H, Tillen D, Dickson R, de Koning K. Action research: a systematic review and guidance for assessment. Health Technol Assess 2001;5(23):iii-157 [FREE Full text] [Medline: $\underline{\text { 11785749] }}$

103. Munn-Giddings C, McVicar A, Smith L. [Systematic review of the uptake and design of action research in published nursing research, 2000-2005]. Rech Soins Infirm 2010 Mar(100):124-133. [Medline: 20419948]

104. Munten G, van den Bogaard J, Cox K, Garretsen H, Bongers I. Implementation of evidence-based practice in nursing using action research: a review. Worldviews Evid Based Nurs 2010 Sep;7(3):135-157. [doi: 10.1111/j.1741-6787.2009.00168.x] [Medline: 19778316$]$

105. Soh K, Davidson P, Leslie G, Bin Abdul Rahman A. Action research studies in the intensive care setting: a systematic review. Int J Nurs Stud 2011 Feb;48(2):258-268. [doi: 10.1016/j.ijnurstu.2010.09.014] [Medline: 21030021]

106. Argyris C, Putnam R, Smith D. Action Science:Concepts, Methods, and Skills for Research and Intervention. San Francisco, CA: Jossey Bass; 1985.

107. Bush P, Pluye P, Loignon C. Improving health organization practices through participatory research - is it worth it? A participatory systematic mixed studies review poster presentation. 2014 Presented at: Annual Conference North American Primary Care Research Group; 2014; New York URL: https://www.mcgill.ca/familymed/files/familymed/ rd seminar paula bush 2014-10-16.pdf

108. Pluye P, Hong QN. Combining the power of stories and the power of numbers: mixed methods research and mixed studies reviews. Annu Rev Public Health 2014;35:29-45. [doi: 10.1146/annurev-publhealth-032013-182440] [Medline: 24188053]

109. Creswell J, Plano Clark V. Designing and conducting mixed methods research. Thousand Oaks: Sage; 2011.

110. Schwartz-Shea P, Yanow D. Interpretive Research Design: Concepts and Processes. New York: Routledge; 2013.

111. Patton M. Qualitative Research \& Evaluation Methods. Thousand Oaks: Sage; 2005.

112. Abbott A. The causal devolution. Sociol Methods Res 1998 Jun 30;27:148-181. [doi: 10.1177/0049124198027002002]

113. Amirault M, Cobbett S, Doherty A. Consumer health information on the internet. J Can Health Libr Assoc 2005;26(2):41-46. [doi: $10.1093 /$ her/16.6.671]

114. Fereday J, Muir-Cochrane E. Demonstrating rigor using thematic analysis: a hybrid approach of inductive and deductive coding and theme development. Int J Qual Methods 2006 Nov 29;5(1). [doi: 10.1177/160940690600500107]

115. Boyatzis R. Transforming Qualitative Information: Thematic Analysis and Code Development. Thousand Oaks: Sage; 1998.

116. Pavel S, Nolet D. Précis de terminologie / Handbook of Terminology. Ottawa: Minister of Public Works and Government Services Canada, Terminology and Standardization; 2001.

117. Clark D, Nicholas D, Jamali HR. Evaluating information seeking and use in the changing virtual world: the emerging role of Google Analytics. Learn Pub 2014 Jul 01;27(3):185-194. [doi: 10.1087/20140304]

118. Turner SJ. Website statistics 2.0: using Google Analytics to measure library website effectiveness. Tech Serv Q 2010 May 28;27(3):261-278. [doi: 10.1080/07317131003765910] 
119. Crutzen R, Roosjen JL, Poelman J. Using Google Analytics as a process evaluation method for internet-delivered interventions: an example on sexual health. Health Promot Int 2013 Mar;28(1):36-42. [doi: 10.1093/heapro/das008] [Medline: 22377974]

120. McGuckin C, Crowley N. Using Google Analytics to evaluate the impact of the CyberTraining project. Cyberpsychol Behav Soc Netw 2012 Nov;15(11):625-629. [doi: 10.1089/cyber.2011.0460] [Medline: 23075266]

121. Pampalon R, Hamel D, Gamache P, Simpson A, Philibert M. Validation of a deprivation index for public health: a complex exercise illustrated by the Quebec index. Chronic Dis Inj Can 2014 Feb;34(1):12-22 [FREE Full text] [Medline: 24618377]

122. Pampalon R, Hamel D, Gamache P, Philibert MD, Raymond G, Simpson A. An area-based material and social deprivation index for public health in Québec and Canada. Can J Public Health 2012 Apr 30;103(8 Suppl 2):S17-S22. [Medline: 23618066]

123. François T. Louvain, Belgique: Centre de Traitement Automatique du Langage, Université Catholique de Louvain (UCL); 2011. Les apports du traitement automatique des langues à la lisibilité du français langue étrangère PhD thesis URL: http:/ /old.atala.org/IMG/pdf/Francois-TAL54-1-2.pdf [accessed 2018-10-12] [WebCite Cache ID 736owyhMn]

124. Sandelowski M. What's in a name? Qualitative description revisited. Res Nurs Health 2010 Feb;33(1):77-84. [doi: 10.1002/nur.20362] [Medline: 20014004]

125. Campbell M, Fitzpatrick R, Haines A, Kinmonth AL, Sandercock P, Spiegelhalter D, et al. Framework for design and evaluation of complex interventions to improve health. Br Med J 2000 Sep 16;321(7262):694-696 [FREE Full text] [Medline: $\underline{10987780]}$

126. Eccles M, Grimshaw J, Campbell M, Ramsay C. Research designs for studies evaluating the effectiveness of change and improvement strategies. Qual Saf Health Care 2003 Feb;12(1):47-52 [FREE Full text] [Medline: 12571345]

127. Craig P, Dieppe P, Macintyre S, Michie S, Nazareth I, Petticrew M, Medical Research Council Guidance. Developing and evaluating complex interventions: the new Medical Research Council guidance. Br Med J 2008 Sep 29;337:a1655 [FREE Full text] [Medline: 18824488]

128. Curry LA, Nembhard IM, Bradley EH. Qualitative and mixed methods provide unique contributions to outcomes research. Circulation 2009 Mar 17;119(10):1442-1452. [doi: 10.1161/CIRCULATIONAHA.107.742775] [Medline: 19289649]

129. Lewin S, Glenton C, Oxman A. Use of qualitative methods alongside randomised controlled trials of complex healthcare interventions: methodological study. Br Med J 2009 Sep 10;339:b3496. [doi: 10.1136/bmj.b3496]

130. Malterud K. The art and science of clinical knowledge: evidence beyond measures and numbers. Lancet 2001 Aug 04;358(9279):397-400. [doi: 10.1016/S0140-6736(01)05548-9] [Medline: 11502338]

131. Shaw I. Qualitative research and outcomes in health, social work and education. Qual Res 2016 Aug 15;3(1):57-77. [doi: $10.1177 / 146879410300300103]$

132. Miles M, Huberman M, Saldana J. Qualitative Data Analysis: A Methods Sourcebook. London: SAGE; Apr 2013.

133. Gallagher F. La recherche descriptive interprétative. In: Méthodes qualitatives, quantitatives et mixtes. Montreal: Presses de l'Université du Québec; 2014:5-28.

134. Creswell J. Qualitative inquiry and research design: Choosing among five approaches. Thousand oaks: Sage; 2007.

135. Morse JM. Critical Issues in Qualitative Research Methods. Thousand Oaks: Sage Publications; 1994.

136. Bamberg M. Stories: big or small. Narrat Inq 2006 Aug 29;16(1):139-147. [doi: 10.1075/ni.16.1.18bam]

137. Newman TB. The power of stories over statistics. Br Med J 2003 Dec 20;327(7429):1424-1427 [FREE Full text] [doi: 10.1136/bmj.327.7429.1424] [Medline: 14684635 ]

138. Sools A. Narrative health research: exploring big and small stories as analytical tools. Health (London) 2013 Jan;17(1):93-110. [doi: 10.1177/1363459312447259] [Medline: 22694917]

139. Nieuwboer CC, Fukkink RG, Hermanns JM. Online programs as tools to improve parenting: a meta-analytic review. Children Youth Serv Rev 2013 Nov;35(11):1823-1829. [doi: 10.1016/j.childyouth.2013.08.008]

140. Godin G. [Behaviors in the Field of Health]. Montréal: Presses de l'Université de Montréal; 2012.

141. Renaud L. [Internet and health promotion]. Montréal: Presses de l'Université du Québec; 2012:133-148.

142. Thoër C. Internet: un facteur de transformation de la relation médicin-patient. Communiquer 2013:1-24 [FREE Full text] [doi: $10.4000 /$ communiquer.506]

143. Romeyer H. La santé en ligne [in French]. Communication 2012;30(1):1-22.

144. Masi CM, Suarez-Balcazar Y, Cassey MZ, Kinney L, Piotrowski ZH. Internet access and empowerment: a community-based health initiative. J Gen Intern Med 2003 Jul;18(7):525-530 [FREE Full text] [Medline: 12848835]

145. Fishbein M, Ajzen I. Predicting and Changing Behavior: The Reasoned Action Approach. London: Psychology Press; 2010.

146. Cihr-irsc. 2015. CIHR 2015-2018 Action Plan for Official Languages URL: http://www.cihr-irsc.gc.ca/e/47951.html [accessed 2018-10-05] [WebCite Cache ID 72wv4UuFN]

147. Commissioner of Official Languages. Officiallanguages.gc. Ottawa: Government of Canada, Minister of Public Services and Procurement Early childhood: Fostering the vitality of francophone minority communities URL: http://www. officiallanguages.gc.ca/en/publications/other/2016/early-childhood-report [accessed 2018-10-05] [WebCite Cache ID 72wv9hLDU] 
148. Greenhalgh T, Robert G, Macfarlane F, Bate P, Kyriakidou O. Diffusion of innovations in service organizations: systematic review and recommendations. Milbank Q 2004;82(4):581-629 [FREE Full text] [doi: 10.1111/j.0887-378X.2004.00325.x] [Medline: 15595944$]$

149. Milat AJ, Newson R, King L, Rissel C, Wolfenden L, Bauman A, et al. A guide to scaling up population health interventions. Public Health Res Pract 2016 Jan 28;26(1):e2611604 [FREE Full text] [doi: 10.17061/phrp2541543] [Medline: 26863167]

150. Milat AJ, Bauman A, Redman S. Narrative review of models and success factors for scaling up public health interventions. Implement Sci 2015 Aug 12;10(17):113-141 [FREE Full text] [doi: 10.1186/s13012-015-0301-6] [Medline: 26264351]

151. Information Technology Primary Care Research Group. Mcgill. The Information Assessment Method (IAM) URL: https:/ /www.mcgill.ca/familymed/research/projects/itpcrg [accessed 2018-10-05] [WebCite Cache ID 72wvH5qH8]

152. Unité de soutien SRAP Québec. URL: http://unitesoutiensrapqc.ca/ [accessed 2018-10-05] [WebCite Cache ID 72wvU9bHu]

153. Brillon K. L'usage et l'appropriation de l'Internet-santé: le cas des mères de famille thesis. Ottawa: Département de communication, Université d'Ottawa; 2015.

154. Thoër C, Lévy J. Internet et santé. Montréal: Presses de l'Université du Québec; 2012.

155. Dholakia UM. How customer self-determination influences relational marketing outcomes: evidence from longitudinal field studies. J Mark Res 2006;43(1):109-120. [doi: 10.1509/jmkr.43.1.109]

156. Dwyer F, Schurr P, Oh S. Developing buyer-seller relationships. J Mark 1987;51(2):11-27. [doi: 10.2307/1251126]

157. Leenheer J. The effectiveness of relational marketing instruments. Medium Econometrische Technieken 2006;14(1):20-24 [FREE Full text]

158. Palmatier R, Dant R, Grewal D, Evans K. Factors influencing the effectiveness of relationship marketing: a meta-analysis. J Mark 2006;70(4):136-153. [doi: 10.1509/jmkg.70.4.136]

159. Brownson RC, Diez RA, Swartz K. Commentary: generating rigorous evidence for public health: the need for new thinking to improve research and practice. Annu Rev Public Health 2014;35:1-7. [doi: 10.1146/annurev-publhealth-112613-011646] [Medline: 24328987]

\author{
Abbreviations \\ AKH: AboutKidsHealth \\ CDIAP: Canadian Deprivation Index Assignment Program \\ CIHR: Canadian Institutes of Health Research \\ IAM: Information Assessment Method \\ IRB: institutional review board \\ N\&G: Naître et grandir \\ NPI: nominated principal investigator \\ OPR: organizational participatory research \\ SES: socioeconomic status
}

Edited by G Eysenbach; submitted 21.03.18; peer-reviewed by C Robillard, P Holtz; comments to author 11.05.18; revised version
received 24.07.18; accepted 14.08.18; published 20.11.18
Please cite as:
Pluye P, Loignon C, Lagarde F, Doray G, El Sherif R, Granikov V, Gonzalez Reyes A, Bujold M, Grad R, Bartlett G, Barwick M,
Schuster T, Turcotte E, Bouthillier F
Assessing and Improving the Use of Online Information About Child Development, Education, Health, and Well-Being in Low-Education,
Low-Income Parents: Protocol for a Mixed-Methods Multiphase Study
JMIR Res Protoc $2018 ; 7(11):$ :186
URL: http://www.researchprotocols.org/2018/11/e186/
doi: $10.2196 /$ resprot.9996
PMID: $\underline{30459143}$

CPierre Pluye, Christine Loignon, François Lagarde, Geneviève Doray, Reem El Sherif, Vera Granikov, Araceli Gonzalez Reyes, Mathieu Bujold, Roland Grad, Gillian Bartlett, Melanie Barwick, Tibor Schuster, Emmanuelle Turcotte, France Bouthillier. Originally published in JMIR Research Protocols (http://www.researchprotocols.org), 20.11.2018. This is an open-access article distributed under the terms of the Creative Commons Attribution License (https://creativecommons.org/licenses/by/4.0/), which permits unrestricted use, distribution, and reproduction in any medium, provided the original work, first published in JMIR Research Protocols, is properly cited. The complete bibliographic information, a link to the original publication on http://www.researchprotocols.org, as well as this copyright and license information must be included. 